\title{
Potentially toxic elements distribution in the contaminated bottom sediments by the industrial genesis within Lower Don river system
}

\author{
Dina Nevidomskaya", Tatiana Minkina, Yuri Fedorov, Yuri Litvinov, Alexei Shcherbakov, \\ Alexei Sherstnev, Mahmoud Mazarji
}

Southern Federal University, 344006 Rostov-on- Don, Russian Federation

\begin{abstract}
The work presents the results of studying the content of potentially toxic elements $(\mathrm{Mn}, \mathrm{Cu}, \mathrm{Zn}, \mathrm{Cr}, \mathrm{Pb}, \mathrm{Ni}$ and $\mathrm{Cd})$ in bottom sediments sampled at monitoring stations in the natural-anthropogenic systems of the Lower Don adjacent to the impact zone of the Novocherkassk Power Plant. The relationship between the content of metals in bottom sediments and their sorption properties is largely determined by the conditions of formation and the type of bottom sediments. Evaluation of the potentially toxic element content in sediments indicated that in particle size fractions $(\leq 0.001 \mathrm{~mm})$ could accumulate more than 15 times the levels of $\mathrm{Cr}$ and $\mathrm{Zn}$ and more than 6 times the levels of $\mathrm{Cu}, \mathrm{Cd}$ and $\mathrm{Ni}$ in comparison to the particle size fractions that are $1.0 \mathrm{~mm}$. Local zones of polyelemental pollution of bottom sediments with respect to $\mathrm{Cu}, \mathrm{Zn}, \mathrm{Pb} \mathrm{Cd}$ and $\mathrm{Cr}$ were determined. These zones are confined to the geochemical sorption barriers of small watercourses of the power plant.
\end{abstract}

\section{Introduction}

Presently industrial clusters greatly influence the features of sediment genesis with form natural-anthropogenic systems [1-4]. They determine the further mechanisms of formation of the elemental composition in the components of aquatic and terrestrial ecosystems. The hydrochemical and hydrological regimes of small rivers experiencing a particularly strong impact directly depend on the intensity at them drainage basins' anthropogenic activity. With the active use of natural resources, the systems of small rivers have changed into receivers of contaminated surface runoff from the territories of adjacent industrial zones. Geochemical processes occurring in rivers play a decisive role in the further redistribution of pollutants. The water mass links pollution sources and various components that make up the river ecosystem, which is represented by aquatic organisms and bottom sediments. Bottom sediments are polydisperse components of aquatic landscapes and serve as a link in biogeochemical processes, controlling the accumulation, redistribution, and mass transfer

* Corresponding author: dnevidomskaya@mail.ru 
of chemical elements [5]. Numerous works have shown that for rivers experiencing an active anthropogenic impact, the factors limiting the presence of elements in a free-ionic form (the most dangerous form for aquatic organisms) is sulfate-sulfide equilibrium in bottom sediments [6-7]. This work aims to study the features of the elemental composition of bottom sediments of the Lower Don river system adjacent to Novocherkassk Power Plant.

\section{Materials and methods}

The study area is located in the south of the East European Plain in the Lower Don geomorphological region and has a braided hydrographic network. Watercourses are represented by small rivers Aksai and Tuzlov with tributaries Grushevka and Kadamovka, which are part of the Don River system. Since 1965, Novocherkassk Power Plant (NchGRES) is one of the largest thermal power plants in southern Russia, has been operating in this area [8]. NchGRES is surrounded by floodplain meadow landscapes. The field expeditions were carried out from spring to fall 2020. To identify the elemental composition of bottom sediments, 9 monitoring stations were established. The location of monitoring stations gives a sense of the sources of input, migration flows and accumulation's zones of potentially toxic elements in small steppe rivers of the study area. The locations of monitoring stations of bottom sediments are shown in Fig. 1.
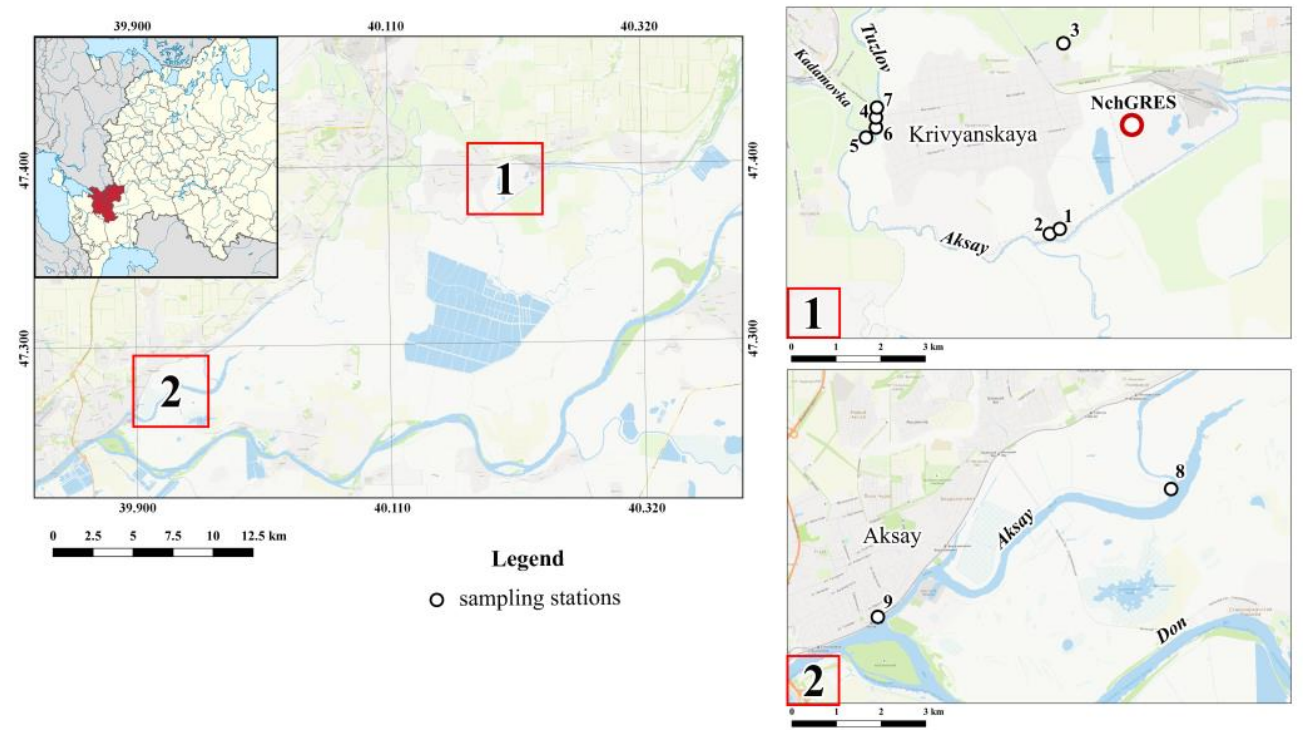

Fig. 1. Location of monitoring stations of bottom sediments of the Lower Don river system adjacent to Novocherkassk Power Plant.

The territory of the NchGRES are complex migration flows-anomalies of dispersion, which are directed towards the Tuzlov and Aksai floodplains landscapes, being a stable source of water pollution in the rivers [4]. Coastal bottom sediments were sampled using a bottom grab "Ocean-0.025". The main dimensional units determined the particle size distribution of bottom sediments: sand, gravel, silt, pelite [5]. The total concentrations of $\mathrm{Mn}, \mathrm{Cu}, \mathrm{Zn}, \mathrm{Cr}, \mathrm{Pb}$, Ni and $\mathrm{Cd}$ in the bottom sediment samples were determined by X-ray fluorescent scanning spectrometer, SPECTROSCAN MAKC-GV). 


\section{Results and discussion}

The results of the study showed that the Aksai, Kadamovka, and, especially, Tuzlov small rivers actively meander, the flow rates of the water flow are very low. In this regard, the flow rates do not exceed $0.1-0.2 \mathrm{~m} / \mathrm{sec}$. This promotes the formation of mechanical sorption geochemical barriers with the formation of sedimentation zones. Technogenic flows continuously coming from NchGRES are superimposed on difficult natural conditions since the dominant components of emissions from the NchGRES are ash, sulfur dioxide, nitrogen oxides [8]. As a result, pollution centers with the domination of gley and hydrogen sulfide geochemical barriers have been formed in the bottom sediments of the Tuzlov and Kadamovka small rivers. The content of potentially toxic elements in the samples of bottom sediments showed that the highest contents of $\mathrm{Cu}, \mathrm{Zn}$ and $\mathrm{Pb}$ are confined to the bottom sediments of the stations of the Tuzlov and Kadamovka small rivers where gleyic and hydrosulfuric geochemical barriers are formed (Table 1).

Table 1. Content of $\mathrm{Mn}, \mathrm{Cu}, \mathrm{Zn}, \mathrm{Cr}, \mathrm{Pb}, \mathrm{Ni}$ and $\mathrm{Cd}$ in bottom sediments of some stations of the study area and their confinement to barrier zones, $\mathrm{mg} / \mathrm{kg}$.

\begin{tabular}{|l|c|c|c|c|c|c|c|}
\hline \multicolumn{1}{|c|}{$\begin{array}{c}\text { Monitoring stations and } \\
\text { material composition }\end{array}$} & Cu & Pb & Zn & Mn & Ni & Cr & Cd \\
\hline $\begin{array}{l}\text { Mechanical sorption gleyic } \\
\text { barrier, fine aleuritic silt, escape } \\
\text { canal No. 1 NchGRES (station } \\
\text { No 1) }\end{array}$ & 50 & 24 & 210 & 870 & 53 & 160 & 0.20 \\
\hline $\begin{array}{l}\text { Mechanical sorption } \\
\text { hydrosulfuric barrier, fine } \\
\text { aleuritic silt, confluence of the } \\
\text { tributary Kadamovka into the } \\
\text { Tuzlov River (station No 6) }\end{array}$ & 79 & 29 & 200 & 1050 & 65 & 125 & 0.38 \\
\hline $\begin{array}{l}\text { Barrier-free landscape, fine sand, } \\
\text { Aksai River (station No 1) }\end{array}$ & 12 & 12 & 10 & 170 & 8 & 40 & 0.09 \\
\hline $\begin{array}{l}\text { Mechanical sorption barrier, } \\
\text { coarse aleuritic silt, confluence } \\
\text { of the Tuzlov River into the } \\
\text { Aksai River (station No 5) }\end{array}$ & 21 & 14 & 49 & 300 & 16 & 69 & 0.11 \\
\hline $\begin{array}{l}\text { Mechanical sorption gleyic } \\
\text { barrier, fine aleuritic silt, Tuzlov } \\
\text { River (station No 4) }\end{array}$ & 60 & 40 & 300 & 2000 & 60 & 200 & 0.27 \\
\hline $\begin{array}{l}\text { Mechanical sorption } \\
\text { hydrosulfuric barrier, fine } \\
\text { aleuritic silt, Kadamovka River } \\
\text { (station No 3) }\end{array}$ & 100 & 80 & 300 & 1000 & 60 & 300 & 0.93 \\
\hline \begin{tabular}{l} 
Clark lithosphere [9] \\
\hline
\end{tabular} & 47 & 16 & 83 & 1000 & 58 & 83 & 0.13 \\
\hline
\end{tabular}

The contents of Ni varies from 16 to $65 \mathrm{mg} / \mathrm{kg}$, the $\mathrm{Pb}$ content from 12 to $80 \mathrm{mg} / \mathrm{kg}, \mathrm{Cu}$ from 12 to $100 \mathrm{mg} / \mathrm{kg}$, and the Cd content from 0.09 to $0.93 \mathrm{mg} / \mathrm{kg}$. The contents of $\mathrm{Cr}, \mathrm{Zn}$ and $\mathrm{Mn}$ are found to be 40 to $300 \mathrm{mg} / \mathrm{kg}, 10$ to $300 \mathrm{mg} / \mathrm{kg}$, and 170 to $2000 \mathrm{mg} / \mathrm{kg}$, respectively. The assessment of the level of pollution was carried out by comparing with the clarke values according to Vinogradov [9]. As given in Table 1, the highest values of $\mathrm{Cu}$ content $(100 \mathrm{mg} / \mathrm{kg})$ were found in the bottom sediments of the river - Kadamovka on a mechanical sorption hydrosulfuric barrier. The surface waters of arid rivers in the south of Russia can contain rather high Mn concentrations [10]. In the analyzed samples, the Mn content ranges from 170 to $2000 \mathrm{mg} / \mathrm{kg}$. However, the natural source of this element in the 
study region does not pose a serious environmental hazard [10]. With an increase in water temperature in summer and autumn, the concentration of dissolved oxygen decreases due to its intensive consumption for biochemical processes [6-7]. Reducing conditions are promoted the formation of mechanical sorption barriers in bottom sediments and lead to the accumulation of potentially toxic elements.

The average total content of elements in sediments can be represented as a successively decreasing series: $\mathrm{Mn}>\mathrm{Zn} \geq \mathrm{Cr}>\mathrm{Cu} \geq \mathrm{Ni} \geq \mathrm{Pb}>\mathrm{Cd}$.

The properties of bottom sediments play an important role in the accumulation of metals, particularly the particle size distribution [11-13] (Fig. 2). Evaluation of the potentially toxic element content in sediments from the natural-anthropogenic systems of the Lower Don indicated that in particle size fractions $(\leq 0.001 \mathrm{~mm})$ could accumulate more than 15 times the levels of $\mathrm{Cr}$ and $\mathrm{Zn}$ and more than 6 times the levels of $\mathrm{Cu}, \mathrm{Cd}$ and $\mathrm{Ni}$ in comparison to the particle size fractions that are $1.0 \mathrm{~mm}$.

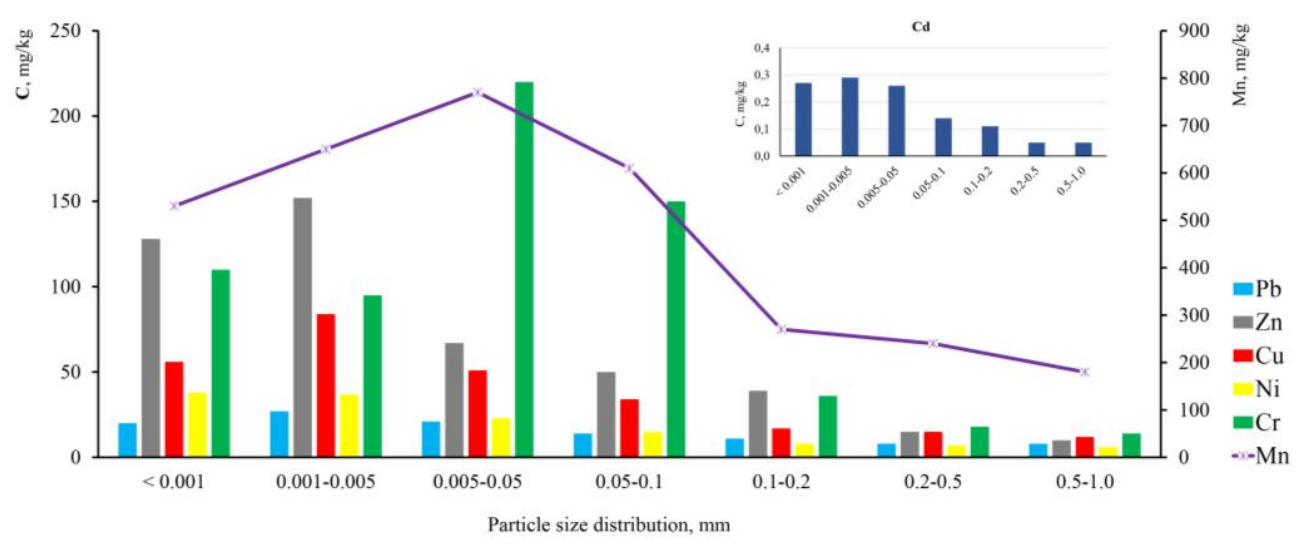

Fig. 2. The content of potentially toxic elements by the particle size distribution of bottom sediments sampled from monitoring station No. 5 confluence of the Tuzlov River into the Aksai River, mg/kg.

The specific surface area of the particles increases with a decrease in dispersion. Hence, the specific surface area will contribute to the removal of elements from the aqueous solution by sorption mechanism occurring on the surface of the material of bottom sediments. Lower content elements characterize bottom sediments with a pelite-aleuritepsammitic composition (station No. 2, 9), sometimes even lower than the clarke than the samples of bottom sediments with aleurite-pelitic composition (stations No. 3, 4, 6). Analyses of potentially toxic element levels in particle size distribution showed that fine particles with high elemental content had tendency to be accumulate at locations where rivers currents are lower.

\section{Conclusions}

The results showed that at the studied sampling stations of bottom sediments, in naturalanthropogenic systems, the focus of pollution arises. Chalcophilic elements accumulate on the hydrogen sulfide barrier. It showed that $\mathrm{Cu}, \mathrm{Pb}, \mathrm{Zn}, \mathrm{Cd}$, and $\mathrm{Cr}$ exceed Clarke's established values. Analysis of particle size distribution of bottom sediments showed that the content of elements increases with a decrease in dispersion. With an increase in water temperature in summer and autumn, the concentration of dissolved oxygen decreases due to its intensive consumption for biochemical processes. Reducing conditions are promoted the formation of mechanical sorption barriers in bottom sediments and lead to the accumulation 
of potentially toxic elements. Thus, local zones of pollution of bottom sediments are noted on the geochemical barriers of small streams of the impact area of the power plant.

The research was financially supported by the Ministry of Science and Higher Education of the Russian Federation within the framework of the state task in the field of scientific activity (no. 08522020-0029) and the Russian Foundation for Basic Research, project no. 19-05-50097.

\section{References}

1. A. Nikanorov, A. Stradomskaya, Water Resour. 34, 3 (2007)

2. T. Minkina, D. Nevidomskaya, T. Pol'shina, Yu. Fedorov, S. Mandzhieva, V. Chaplygin, T. Bauer, M. Burachevskaya, J. Soils Sediments 17, 5 (2017)

3. E. Yanin, Geochemistry Int. 51, 9 (2013)

4. T. Minkina, S. Mandzhieva, V. Chaplygin, G. Motuzova, M. Burachevskaya, T. Bauer, S. Sushkova, D. Nevidomskaya, Eurasian Soil Sci. 50, 6 (2017)

5. Yu. Fedorov, I. Dotsenko, A. Mikhailenko, In Conference Proceedings of 15th International Multidisciplinary Scientific GeoConference SGEM, 1 (2015)

6. L.J. Ehlers, R.G. Luthy, Environ. Sci. Technol. 37, 15 (2003)

7. T. Moiseenko, Geochemistry Int. 57, 7 (2019)

8. V. Linnik, T. Minkina, T. Bauer, A. Saveliev, S. Mandzhieva, Environ Geochem Health (2019), https://doi.org/10.1007/s10653-019-00361-z

9. A.P. Vinogradov, Geochemistry, 7 (1962)

10. A. Nikanorov, A. Stradomskaya, Water Resour. 33, 1 (2006)

11. G. Benoit, T. Rozan, Geochem. Cosmochim. Acta. 63, 1 (1999).

12. B. Tansel, S. Rafiuddin, Int. J. Sediment Res. 31, 4 (2016)

13. A. Apler, I. Snowball, P. Frogner-Kockum, S. Josefsson, Chemosphere, 215 (2019) 